\section{Jesuits and the Modern Chinese University}

\section{Ruth Hayhoe}

Ruth Hayhoe is professor of higher education and vice dean of the Faculty of Education, University of Toronto. Address: Faculty of Education, 252 Bloor St., W. Toronto, Ontario M5S 1V6, Canada.

$\mathrm{T}$ he development of modern universities in China has fascinating connections to the story of one man, a Chinese Jesuit, whose vision for Chinese-Western cultural and intellectual cooperation has. to this day, never been fully realized. Ma Xiangbo was born in 1840, the first year of the Opium Wars, and died in the darkest days of the Japanese occupation of China in 1939. He was the mentor and teacher of some of China's most famous political and intellectual figures of the late Qing and early republican periods, including Liang Qichao and Cai Yuanpei, and was a senior adviser to political figures such as Yuan Shikai and Chiang Kaishek. He was also an outspoken advocate for the indigenization of the Catholic Church in China, and a tireless campaigner against the French Protectorate, which gave France jurisdiction over the Catholic community in China and prevented direct relations with the Vatican up to 1905.

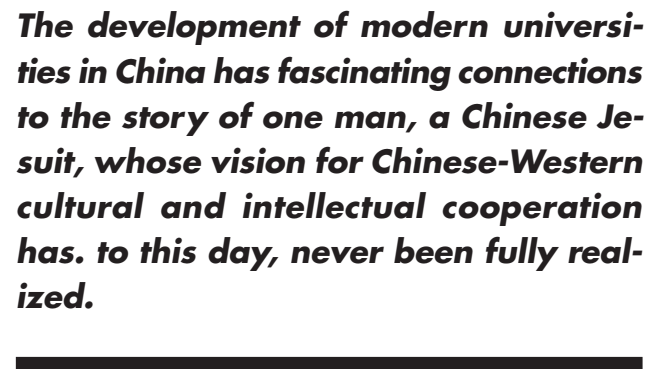

Ma's first educational role was as principal of the College St. Ignace, one of the earliest Western-style secondary schools in Shanghai, which was founded in 1851 not long after the Jesuits returned to China in 1837 after a 60year ban. Ma had entered the school as a student in 1852 , went on to seminary studies in 1862, graduated with a doctorate in 1872 , and held the role of principal from then up to 1875 . The curriculum Ma devised for the school included a strong emphasis on Chinese classical literature and history as the basis, supplemented by advanced studies in Western mathematics, languages, and philosophy, following Jesuit patterns. Ma's emphasis on Chinese studies aroused suspicion among the French priests, and this pressure resulted in his resignation from the Jesuit Order in 1876.

After 25 years spent in diplomacy and modernization projects for the Qing imperial government, Ma returned to educational concerns in 1900 with the intention of founding "a new-style university that would keep pace with Western universities." He donated his considerable family properties to the Jesuits as an endowment for l'Université Aurore, which opened its doors in 1903. Aurore offered a curriculum that focused on basic sciences and Western classical literature, and Ma put considerable effort into preparing a philosophy textbook that used Chinese classical concepts to introduce Western philosophy rather than the modish, yet often inappropriate, modern terms being introduced from Japan at the time. His vision was to enable Chinese youth to gain a fundamental understanding of Western thought, in both the natural sciences and literary and philosophical studies, in order to create conditions for a critical and self-reflective approach to nation building.

\section{Fudan University first achieved fame for its leadership of the May 4th movement of 1919 in Shanghai, and both its fac- ulty and students tended to be highly active politically in the subsequent de- cades.}

However, the French priests involved in this project were determined to create a French Catholic university, in a spirit of competition with the burgeoning American Protestant colleges of the time. They moved quickly to take control away from $\mathrm{Ma}$ and the mature, politically active students that had gathered around him. By 1905, Ma and the students had no recourse but to leave Aurore and seek help from high-level contacts in government to found Fudan University, whose name signifies a revived Aurore. While the founders' intention was again to lay the foundation for educating Chinese youth in a profound understanding of both Chinese and European traditions of knowledge, this time the new institution was shaped to offer more immediate service to both the political and commercial needs of a society in upheaval. Fudan University first achieved fame for its leadership of the May 4th movement of 1919 in Shanghai, and both its faculty and students tended to be highly active politically in the subsequent decades. However, in the period before 1949, it never gained a reputation for the kinds of scholarship in both European and Chinese foundations of knowledge that Ma saw as an essential basis for the health of China's fledgling republic. 
Ma made two further efforts to create scholarly institutions that could fulfill this role after the revolution of 1911. The Hanxia Academy of Humanities and Sciences was modeled after the Académie Française, and was intended to promote both modern and classical learning in an atmosphere free from any political constraint, and to set literary and scholarly standards for the nation. A particular objective that Ma had in mind was the creation of a common set of modern terms for culture, education, and scholarship that reflected China's own linguistic heritage, in place of the terminology introduced from Japan. Unfortunately, the project failed to gain adequate support, due to the chaotic conditions of the warlord government and a lack of conviction about its importance in the scholarly community. More than a decade later, in 1929, Ma's disciple Cai Yuanpei set up the Academica Sinica, with support from the newly established Nationalist government, and it was succeeded by the Chinese Academy of Sciences after 1949.

\section{Unfortunately, the era of cooperation with the Soviet Union saw a total sub- ordination of the university to political ends, which culminated in their near de- struction during the Cultural Revolution.}

Ma's final effort to create a modern university worthy of the traditions of knowledge and higher learning of both China and the West began with a letter to the Pope in 1912, in which he and a colleague-Ying Lianzhi, a prominent Catholic who was editor of the Da Gong Bao-petitioned for the establishment of a Catholic university in China. In their vision, such a university would serve as a model for the whole nation, and enable "those within the Church to use their scholarship for the service of society" and "those outside the Church through scholarship to receive the true light." Furen University finally came into being in 1926, with the cooperation of American Benedictines, and its early curriculum, designed by Ma, was divided into five areas: theology and philosophy, Chinese and foreign languages, natural sciences, sociology and history, and mining and architecture. For a brief decade, before the Japanese occupation, Furen was able to develop a considerable reputation in both Chinese history and literature and Western-derived humanities. It remained in Beijing under the Japanese occupation, when most of the other universities moved to the hinterland, but after 1949 its campus was given by the Communist regime to the newly established Beijing Normal University, and the ethos it had developed found little resonance in the system of higher education set up under Soviet tutelage.

While Chinese universities have a
magnificent classical heritage to build
upon, fundamental societal change
will result only as their scholars con-
sciously integrate what is introduced
from the West into this heritage.

Ma's vision of a modern university for China placed basic knowledge in philosophy, the humanities, and the sciences at the core. He emphasized the university's responsibility for developing a modern terminology that would synthesize Chinese and Western concepts and create a solid foundation for a Chinese approach to the building of modern institutions. For this to come about, he felt that freedom from pressure to offer direct service to politics, the economy, or religion was essential. Unfortunately, the era of cooperation with the Soviet Union saw a total subordination of the university to political ends, which culminated in their near destruction during the Cultural Revolution, while pressures for commercialization and direct service to the economy have been dominant during the period since 1978.

In many ways Ma's efforts to cooperate with the West, while at the same time insisting on the assertion of Chinese identity at a fundamental cultural and epistemological level, highlight what is most needed and least attended to in relations between Chinese and Western universities. While Chinese universities have a magnificent classical heritage to build upon, fundamental societal change will result only as their scholars consciously integrate what is introduced from the West into this heritage. By the same token, an approach to exchange and cooperation that emphasizes fundamental learning and mutual transformation could be of particular value to higher education in North America in the present era, as the understanding of Asian thought and values has greater and greater urgency with the world's economic center shifting toward East Asia.

For a fuller account of Ma's life and work, as well as translations of important essays by Ma Xiangbo, see Ruth Hayhoe and Lu Yongling, eds., Ma Xiangbo and the Mind of Modern Cbina (New York: M. E. Sharpe, 1996). 